\title{
Defense Genes Are Differentially Induced by a Mycorrhizal Fungus and Rhizobium sp. in Wild-Type and Symbiosis-Defective Pea Genotypes
}

\author{
Juan M. Ruiz-Lozano, Hélène Roussel, Silvio Gianinazzi, and Vivienne Gianinazzi-Pearson \\ Laboratoire de Phytoparasitologie, INRA-CNRS, CMSE-INRA, BV 1540, 21034 Dijon Cedex, France \\ Accepted 4 August 1999.
}

\begin{abstract}
Mycorrhiza-resistant and non-nodulating pea mutants provide a model system for identifying common genes regulated during the early events in mycorrhiza and nodule establishment. Inoculation of pea roots with Glomus mosseae or Rhizobium leguminosarum can induce overexpression of seven defense-related genes (pI 206, pI 49, pI 176, PR 10, basic A1-chitinase, transcinnamic acid 4hydroxylase, chalcone isomerase), depending on the plant genotype and the time point of interaction between the plant and the microsymbiont. Expression of the pI 206 gene is closely correlated with appressorium formation by the mycorrhizal fungus on both mutant and wild-type pea roots. The gene is also induced by the pathogen Aphanomyces euteiches. Transcript accumulation was higher in mutant than in wild-type genotypes for five and six of the studied genes during early stages of root interactions with G. mosseae and R. leguminosarum, respectively, and this is discussed in relation to the symbiotic-defective phenotype of $\mathrm{Myc}^{-1} \mathrm{Nod}^{-}$pea. The early induction of similar plant defense genes in response to arbuscular mycorrhizal fungi and rhizobia reinforces the hypothesis of common regulatory steps in both root symbioses.
\end{abstract}

Additional keywords: gene expression, nodule symbioses, Pisum sativum.

Root colonization by arbuscular mycorrhizal fungi (AMF) and root nodule induction by rhizobia share some cellular and molecular features (Mellor 1989; Perotto et al. 1994; Gollotte et al. 1995; Frühling et al. 1997; Gianinazzi-Pearson and Dénarié 1997; van Rhijn et al. 1997). Common regulating genes have been identified in mycorrhiza-resistant and nonnodulating $\left(\mathrm{Myc}^{-1} \mathrm{Nod}^{-}\right)$pea or Medicago mutants (Duc et al. 1989; Gianinazzi-Pearson et al. 1991; Sagan et al. 1995). Although mycorrhizal infection is not successful in these plants, fungal appressoria are formed, so that early recognition events must occur and inhibition of further fungal development must be linked to plant factors affecting the subsequent stages of mycorrhiza establishment. In the case of rhizobial interactions, root hair curling does not occur (Sagan et al. 1995). As

Corresponding author: Juan Manuel Ruiz-Lozano, Departamento de Microbiología y Sistemas Simbióticos, Estación Experimental del Zaidín (CSIC), Prof. Albareda, 1, 18008 Granada, Spain; Telephone: +34 958121 011; Fax: +34 958129 600; E-mail: jmruiz@eez.csic.es these mutants are unaffected for interactions with other rootinfecting microorganisms (Gianinazzi-Pearson et al. 1994), they provide proof that specific host genes modulate root symbioses and therefore represent model plant material for identifying plant or microbial genes involved in the early events of AM or nodule establishment. Three of these pea mutants are P2, P6, and P54, which are affected in sym 8, sym 19 , and sym 30 genes, respectively, leading to plant resistance to both AMF and rhizobia colonization (Gianinazzi-Pearson 1996).

Expression of host plant defense responses is uncoordinated, weak, and/or very localized during plant-fungal interactions in AM (Morandi et al. 1984; Gianinazzi-Pearson et al. 1992, 1996; Harrison and Dixon 1993; Volpin et al. 1994; Mohr et al. 1998). In $\mathrm{Myc}^{-1}$ mutants, however, AMF elicit important defense-related wall reactions in host cells adjacent to appressoria (Gianinazzi-Pearson et al. 1991; Gollotte et al. 1993, 1996). Interactions between $\mathrm{Nod}^{-}$mutants and rhizobia have not been investigated at the cellular level, and it is still a matter of debate whether rhizobia also induce plant defense responses that have to be overcome for nodulation to occur (Niehaus et al. 1993). Nod factors can induce early, transient, defense responses in cells and roots (Savouré et al. 1997), and it has been proposed that autoregulation of root nodulation involves a defense mechanism similar to those elicited in incompatible rhizobia-legume interactions (Vasse et al. 1993). Gene expression analyses of plant mutants like $\mathrm{Myc}^{-1} \mathrm{Nod}^{-}$ peas, which are unable to form root symbioses but are susceptible to plant pathogens (Gianinazzi-Pearson et al. 1994), could be a valid approach to better understanding events underlying symbiotic interactions.

The role of symbiosis-specific host genes may be to exert some sort of control over the expression of defense genes during symbiosis development, and the resistance phenotype in pea mutants may reflect alterations in these gene functions (Gianinazzi-Pearson 1996). Whether resistance to AMF or Rhizobium spp. in symbiosis-defective mutants involves specific activation of plant defense genes, as in incompatible plant-pathogen interactions (Bowles 1990; Stintzi et al. 1993; Collinge et al. 1994; Dixon et al. 1994), has not previously been determined. In the present investigation, we have made a detailed study of defense gene expression during interactions of wild-type or $\mathrm{Myc}^{-1} \mathrm{Nod}^{-}$pea genotypes with Glomus mosseae (Nicol. \& Gerd.) Gerd. \& Trappe or Rhizobium leguminosarum bv. viciae. The defense genes studied were PR10, pI 49, pI 176, and pI 206, previously reported as in- 
duced during plant-pathogen interactions in pea (Fristensky et al. 1985; Riggleman et al. 1985; Daniels et al. 1987; Fristensky et al. 1988; Hadwiger et al. 1992). The gene encoding for a defense-related basic A1-chitinase in pea (Vad et al. 1993) was also studied. Finally, genes encoding for chalcone isomerase (Wood and Davies 1994) and transcinnamic acid 4hydroxylase (Frank et al. 1996) were also used as probes. These two proteins are involved in production of phytoalexins, an important component of plant defense responses against pathogens (Dixon 1986; Phillips and Kapulnik 1995), also reported to be active during AMF-plant interactions (Harrison and Dixon 1993, 1994).

\section{RESULTS}

\section{Infection development.}

Appressoria formed 3 days after inoculation (dai) with $G$. mosseae on roots of cv. Frisson and to a lesser extent on the P2 mutant (Table 1). The inverse situation was observed at 6 dai, as appressoria were more numerous on roots of mutant plants than on wild-type ones. All stages of mycorrhiza development were present in cv. Frisson at this time point, and root colonization increased to 15 dai, while only appressorium formation increased in P2 and there was no penetration of root tissues by G. mosseae. Appressoria were also the only fungal structures on roots of the mutants P6 (11.1 per cm root) and P54 (7.4 per cm root). No nodules formed on roots of any of the G. mosseae-inoculated or noninoculated plants. Nodules appeared on roots of cv. Frisson plants at 6 dai with $R$. leguminosarum and the number of nodules increased from 50 to 130 per root system between 6 and 15 dai, respectively. Nodules were not present at any time on roots of P2 plants or of noninoculated controls. Both cv. Frisson and P2 roots were susceptible to Aphanomyces euteiches, as previously reported by Gollotte (1993), and infection symptoms were visible by a yellow coloring of the roots 6 dai and by necroses 15 dai.

\section{Transcript accumulation.}

The pI 206 cDNA clone hybridized with a single mRNA species from G. mosseae-inoculated roots (cv. Frisson and P2) and no significant signal was observed in corresponding noninoculated roots (Fig. 1). Signal intensity varied with time and plant genotype. At 3 dai, gene expression was detected only in inoculated cv. Frisson plants, but inoculated P2 roots showed higher levels of mRNA than cv. Frisson 6 dai. Transcripts in-

Table 1. Development of Glomus mosseae on roots of Pisum sativum cv. Frisson or isogenic mutant P2 at different time points after inoculation

\begin{tabular}{|c|c|c|c|c|}
\hline \multirow[b]{2}{*}{ Plant genotype } & \multirow{2}{*}{$\begin{array}{l}\text { Colonization } \\
\text { parameters }^{\mathrm{y}}\end{array}$} & \multicolumn{3}{|c|}{ Days after inoculation } \\
\hline & & 3 & 6 & 15 \\
\hline \multirow[t]{3}{*}{ cv. Frisson } & $\mathrm{App} / \mathrm{cm}$ & $6.5 \mathrm{e}^{\mathrm{z}}$ & $15.0 \mathrm{~d}$ & $27.1 \mathrm{~b}$ \\
\hline & M\% & $0.2 \mathrm{c}$ & $19.4 \mathrm{~b}$ & $44.7 \mathrm{a}$ \\
\hline & A\% & $0 \mathrm{c}$ & $8.2 \mathrm{~b}$ & $33.2 \mathrm{a}$ \\
\hline \multirow[t]{3}{*}{$\mathrm{P} 2$} & $\mathrm{App} / \mathrm{cm}$ & $1.1 \mathrm{f}$ & $22.1 \mathrm{c}$ & $37.4 \mathrm{a}$ \\
\hline & M\% & $0 \mathrm{c}$ & $0 \mathrm{c}$ & $0 \mathrm{c}$ \\
\hline & $\mathrm{A} \%$ & $0 \mathrm{c}$ & $0 \mathrm{c}$ & $0 \mathrm{c}$ \\
\hline
\end{tabular}

\footnotetext{
${ }^{y} \mathrm{App} / \mathrm{cm}$, number of appressoria per $\mathrm{cm}$ of root length; $\mathrm{M} \%$, colonization intensity; A\%, arbuscule frequency.

${ }^{\mathrm{z}}$ Values for each parameter and each time point followed by a different
} letter are significantly different $(P<0.05)$. creased up to 15 dai in both plant genotypes in response to fungal inoculation, and continued to be higher in the P2 mutant. The pI 206 gene was also activated in roots of the P6 and P54 mutants 9 dai with G. mosseae (Fig. 2). A significant correlation was found between the frequency of appressoria formed by $G$. mosseae on roots of the different pea genotypes, and accumulation of pI 206 gene transcripts (Fig. 3). Polymerase chain reaction (PCR) analyses of genomic DNA with pI 206-specific primers gave an amplification product of the expected size with cv. Frisson and P2 mutant DNA but not with G. mosseae DNA, suggesting that pI 206 transcript accumulation is not due to expression of a fungal gene homologue. Furthermore, hybridization of the pI 206 cDNA clone with RNA from pea roots 6 and 15 dai with A. euteiches gave signal intensities similar to those from roots colonized by $G$. mosseae (results not shown). Very low levels of pI 206 mRNA accumulated in roots inoculated with $R$. leguminosarum (Fig. 4 ) and only at 1 dai. Noninoculated roots contained traces of transcripts at this time point. More pI 206 mRNA was detected in the P2 mutant after bacterial inoculation than in $\mathrm{cv}$. Frisson plants. Transcripts dropped to undetectable levels in the roots of all plants at 3,6 , and 15 dai.

The PR 10, pI 49, and pI 176 probes gave similar results in hybridization analyses (Figs. 1, 2, and 4). There were no differences in mRNA accumulation at 3 dai with G. mosseae inoculation or between plant genotypes. Transcript level subsequently increased in inoculated roots of cv. Frisson and P2 plants, compared with noninoculated controls. The two pea genotypes showed different responses to $G$. mosseae between 6 and 15 dai. PR 10, pI 49, and pI 176 transcript accumulation was greatest in $G$. mosseae-inoculated P2 plants at 6 dai but this effect was transient. At 15 dai, lower levels were detected than in inoculated cv. Frisson plants, where an increase was observed between 6 and 15 dai. Noninoculated roots of both genotypes maintained almost constant levels of mRNA accumulation for all three genes at the three time points. Transcript accumulation of PR 10, pI 49, and pI 176 also increased in the pea mutants P6 and P54 (9 dai) in response to fungal inoculation (Fig. 2). Inoculation of $R$. leguminosarum had little effect on the expression of the PR 10, pI 49, or pI 176 genes in roots 1 dai. Only inoculated $\mathrm{P} 2$ roots showed a slight increase of PR 10 and pI 49 gene expression during the first stages of interactions with the bacteria. mRNA levels decreased with time but remained higher in inoculated P2 roots and, to a lesser extent, in inoculated cv. Frisson roots at 3 dai. Levels of mRNA were similar 6 dai in all four treatments and transcript accumulation increased in both genotypes 15 dai, particularly in roots of noninoculated plants.

Northern (RNA) analysis of mRNA coding for basic CHT indicated a lower level of gene expression in pea roots, compared with the other defense genes (Fig. 1). Inoculation with G. mosseae induced higher mRNA levels at all times in both cv. Frisson and the P2 genotype than in noninoculated controls. Roots of the mutants P6 and P54 did not show CHT gene activation 9 dai with $G$. mosseae. Inoculation with $R$. leguminosarum only activated the CHT gene in cv. Frisson 15 dai when numerous nodules had developed (Fig. 4).

$G$. mosseae did not induce significant changes in $\mathrm{tCAH}$ mRNA accumulation at 3 or 6 dai in roots of either cv. Frisson or the mutant P2. Transcript levels later increased in both inoculated plants, mainly in P2. P6 and P54 mutants only 
showed slight induction of gene expression 9 dai with $G$. mosseae (Fig. 2). Inoculation with $R$. leguminosarum only had a transient effect on tCAH mRNA accumulation in P2 mutants, which showed higher levels of transcript accumulation at 1 and 3 dai, compared with all the other treatments. Thereafter, levels of tCAH mRNA were unaffected by either bacterial presence or plant genotype (Fig. 4).

Accumulation of CHI mRNA after inoculation with $G$. mosseae differed little among treatments at 3 dai, but showed a considerable, but transient, increase in inoculated P2 plants 3 dai. At 15 dai, both inoculated genotypes showed higher levels of gene expression than their corresponding controls, but P2 plants did not accumulate more $\mathrm{CHI}$ transcripts than cv. Frisson. Transcript accumulation of both P6 and P54 mu- tants increased in response to inoculation with G. mosseae (9 dai). As for $\mathrm{tCAH}$, inoculation with $R$. leguminosarum had little effect on CHI accumulation and only inoculated P2 plants showed slightly higher transcript levels than the other treatments from 1 to 6 dai. At 15 dai, no significant differences among treatments were observed.

\section{DISCUSSION}

The formation of AM constitutes a massive fungal invasion of plant roots. AMF must, therefore, have dealt very early on in evolution with problems of avoiding, suppressing, or overcoming plant defense responses, tactics that have enabled them to extend to such a widespread number of plant taxa

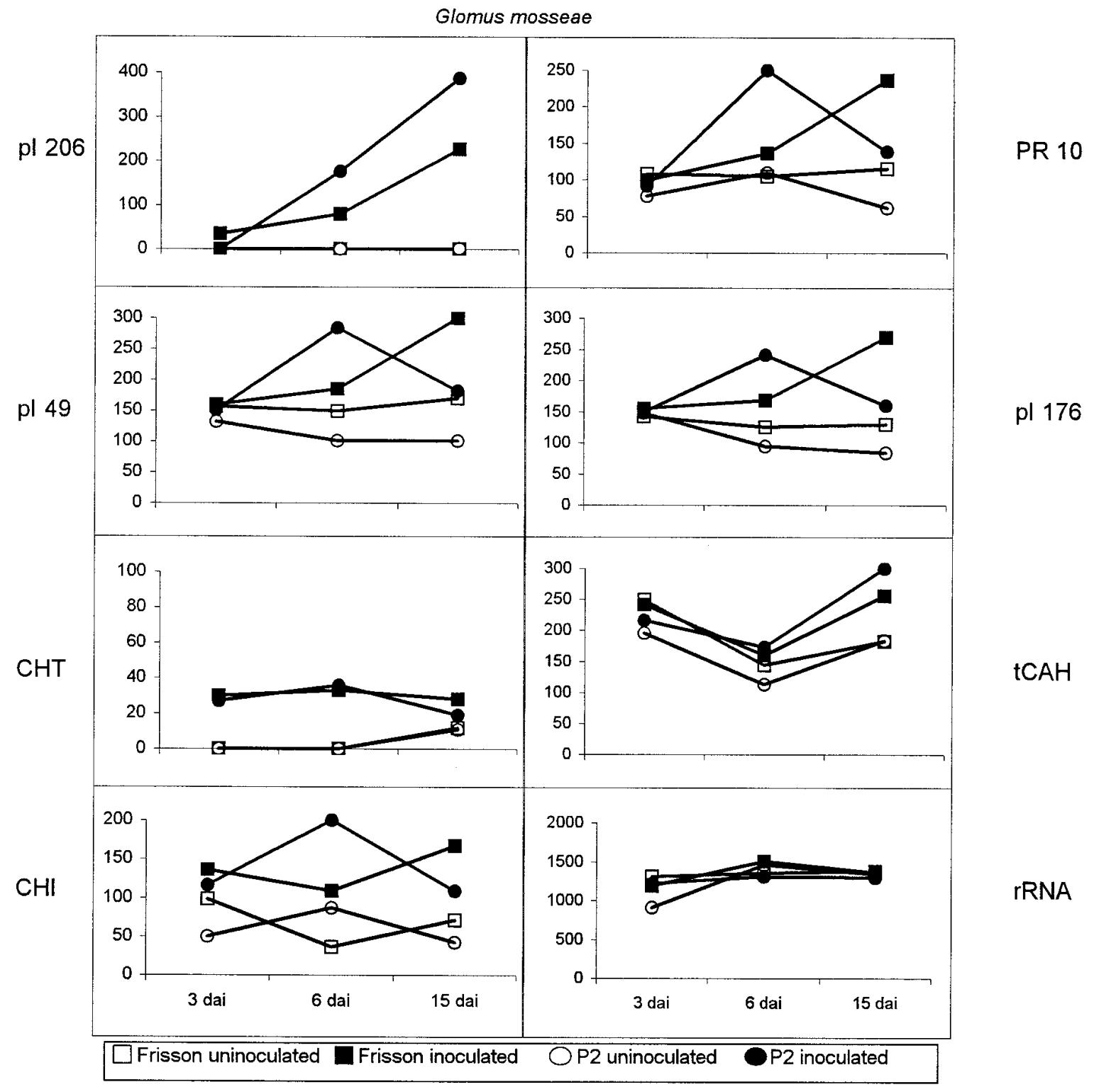

Fig. 1. Transcript accumulation levels at different time points, for seven defense genes in roots of wild-type pea cv. Frisson inoculated or not with Glomus mosseae, or of an $\mathrm{Myc}^{-1} \mathrm{Nod}^{-}$pea mutant (P2) inoculated or not with G. mosseae. rRNA and hybridization signal were quantified with NIH Image software. Transcript levels were normalized to rRNA and are expressed in arbitrary units. CHT, basic A1-chitinase; tCAH, transcinnamic acid 4hydroxylase; $\mathrm{CHI}$, chalcone isomerase. 
(Gianinazzi-Pearson 1996). Nodule symbioses show host specificity, and evidence exists that infection by rhizobia is controlled by the host plant (Calvert et al. 1984; CaetanoAnollés and Bauer 1988; Vasse et al. 1993). This means that

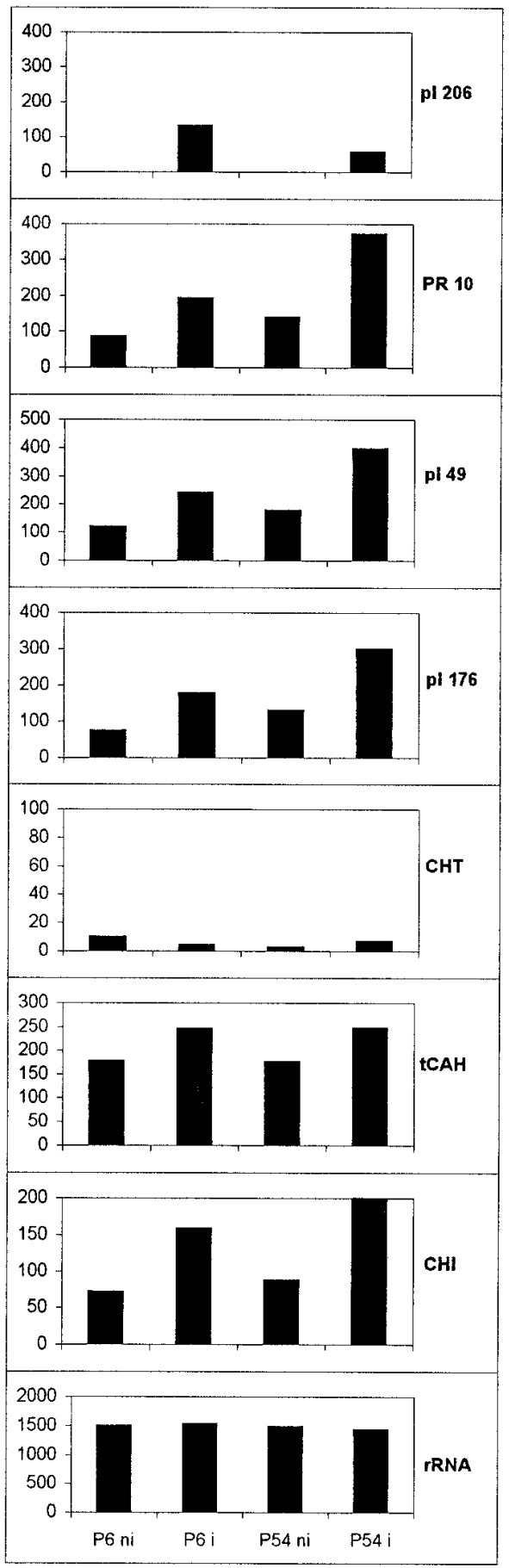

Fig. 2. Transcript accumulation levels for seven defense genes in roots of $\mathrm{Myc}^{-1} \mathrm{Nod}^{-}$pea mutants (P6 or P54) inoculated (i; 9 days after inoculation) or not (ni) with Glomus mosseae. rRNA and hybridization signal were quantified with NIH Image software. Transcript levels were normalized to rRNA and are expressed in arbitrary units. CHT, basic A1chitinase; tCAH, transcinnamic acid 4-hydroxylase; $\mathrm{CHI}$, chalcone isomerase. reciprocal plant-microbe compatibility systems must have developed and been maintained throughout evolution in both symbioses.

The present investigations show that inoculation of pea roots with $G$. mosseae or $R$. leguminosarum induces overexpression of defense-related genes. The pattern and intensity of transcript accumulation differ depending on the gene considered, the plant genotype, the microsymbiont, or the time point after inoculation. In PR 10, pI 49, and pI 176, mRNA accumulation follows a similar pattern. Gene expression occurs in noninoculated plants at different plant ages, but is enhanced in roots 6 and 15 dai with $G$. mosseae and only transiently 1 and 3 dai with $R$. leguminosarum. Genes encoding $\mathrm{pI} 49$ and $\mathrm{pI}$ 176 are members of the multigene PR 10 family (Hadwiger et al. 1992), so their similar pattern of mRNA accumulation is not surprising. They are differentially expressed throughout the growth of pea seedlings, suggesting that they may be involved in plant developmental processes (Hadwiger et al. 1992). PR 10 proteins have been suggested to be RNases, based on significant amino acid sequence similarity with ribonuclease peptides in parsley (Moieyev et al. 1994; Walter et al. 1996), but such enzymatic activity has not been demonstrated so far for any protein of the PR 10 family (Pinto and Richard 1995).

The gene coding for pI 206 is increasingly elicited by $G$. mosseae in susceptible wild-type and symbiosis-defective pea genotypes up to 15 dai but it is only weakly and transiently activated 1 dai in pea roots inoculated with $R$. leguminosarum. Genes encoding pI 49, pI 176, and pI 206 are activated in pea pods not only with nonhost resistance to Fusarium solani f. sp. phaseoli or resistance to Pseudomonas syringae pv. pisi but also in susceptible interactions with $F$. solani f. sp. pisi, although activation is comparably weaker or delayed (Fristensky et al. 1985; Riggleman et al. 1985; Daniels et al. 1987; Fristensky et al. 1988). Elicitation of genes coding for pI 49 and pI 206 in the incompatible pea- $F$. solani interaction is mediated by a heat-stable, extracellular DNase that is released by the pathogen after physical contact with plant tissues (Gerhold et al. 1993; Hadwiger et al. 1995). The pI 206 gene is of particular interest as ex-

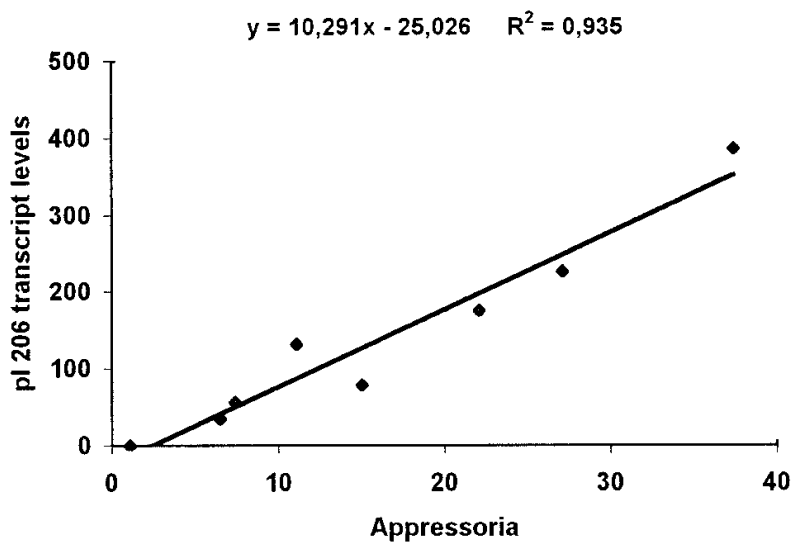

Fig. 3. Correlation between appressorium formation and pI 206 transcript accumulation in Glomus mosseae-inoculated cv. Frisson and mutant (P2, P6, P54) roots. Number of appresoria formed on roots of each pea genotype at different time points was correlated with corresponding pI 206 transcript accumulation level, expressed in arbitrary units. 
pression is linked to appressorium formation in G. mosseaeinoculated pea plants, and activation of this plant defense gene during the first stages of mycorrhizal interactions could depend on a signal molecule produced by $G$. mosseae at the moment of contact with root cells. Appressorium differentiation is a decisive event in fungal recognition and invasion of plant tissues (Staples and Macko 1980). Elicitation of the pI 206 gene also by A. euteiches may mean that this is a general response of pea roots during interactions with rootinfecting fungi.

The transient activation of the basic CHT encoding gene in the different pea genotypes interacting with $G$. mosseae agrees with previous reports of a burst in chitinase activity during early interactions between roots of different plants and AMF
(Spanu et al. 1989; Lambais and Mehdy 1993; Volpin et al. 1994). Pea chitinases inhibit hyphal growth of pathogens but not of mycorrhizal fungi (Arlorio et al. 1991), and basic chitinases have a vacuolar compartmentation so that they will not come into direct contact with walls of actively growing AMF. Consequently, it is unlikely that these defense-related enzymes are essential to the control of AMF along or within roots, and the enhanced expression of corresponding genes may reflect a nonspecific plant response to tissue invasion or invasion attempts (Gianinazzi-Pearson et al. 1996). In $R$. leguminosarum interactions, the enhanced chitinase gene expression uniquely in nodulated cv. Frisson plants 15 dai recalls findings of a chitinase-mediated plant defense reaction in soybean nodules infected by Bradyrhizobium japonicum (Stae-

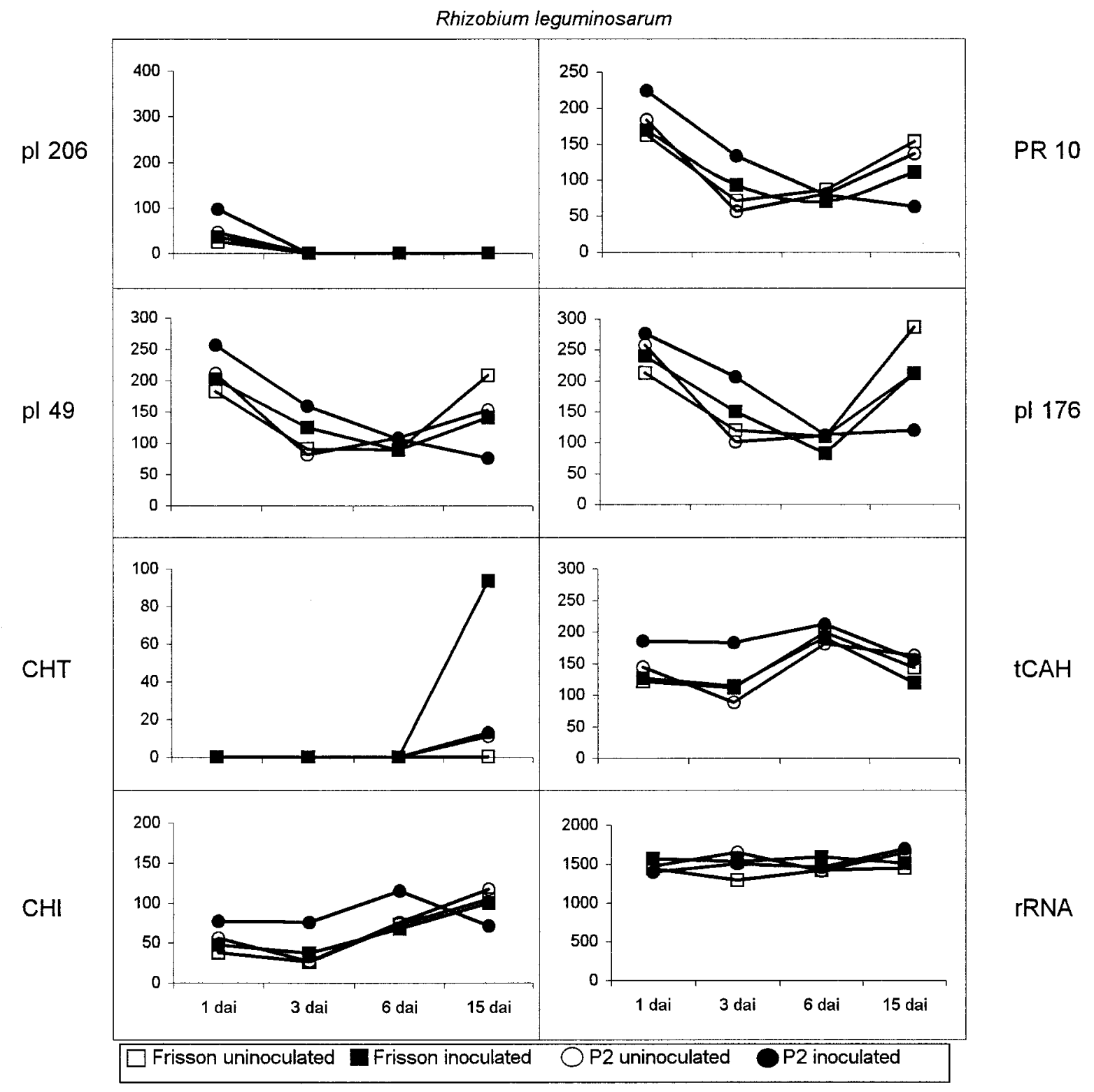

Fig. 4. Transcript accumulation levels at different time points, for seven defense genes in roots of wild-type pea cv. Frisson inoculated or not with Rhizobium leguminosarum, or of an $\mathrm{Myc}^{-1} \mathrm{Nod}^{-}$pea mutant (P2) inoculated or not with $R$. leguminosarum. $\mathrm{rRNA}$ and hybridization signal were quantified with NIH Image software. Transcript levels were normalized to rRNA and are expressed in arbitrary units. CHT, basic A1-chitinase; tCAH, transcinnamic acid 4-hydroxylase; CHI, chalcone isomerase. 
helin et al. 1992; Parniske et al. 1994). However, chitinase expression is also under developmental control and it has been suggested that such an enzyme could have a non-defensive function, for example in the inactivation of Nod factors produced by Rhizobium spp. (Staehelin et al. 1994; Mellor and Collinge 1995).

Although phenylpropanoid metabolism can be enhanced in roots during symbiotic interactions with AMF, this is not a general phenomenon, and the extent and timing depend on the plant and fungal genotypes involved (Morandi et al. 1984; Morandi and Le Quéré 1991; Harrison and Dixon 1993; Lambais and Mehdy 1993; Volpin et al. 1994, 1995). In the present study, expression of genes encoding for tCAH is poorly affected by $\mathrm{AMF}$ and does not seem to reflect a specific defense response. In contrast, levels of CHI mRNA showed a considerable increase in the P2 mutants 3 dai with G. mosseae, suggesting an early, though transient, defenserelated response to the AMF. The same is also observed in the P2 mutants for both tCAH and CHI after inoculation with R. leguminosarum.

It is clear that plant reactions to AMF are mediated by a number of genes and that gene-for-gene mechanisms involving specific plant genes for specific microbial products are unlikely to be active in such widespread symbiosis. Mutation of sym 8, sym 19, and sym 30 genes in pea causes resistance to AMF and rhizobia (Gianinazzi-Pearson 1996), indicating multigenic control of early interactions. At the cellular level, the corresponding mutants (P2, P6, P54) develop defenserelated cell wall modifications in response to AMF (Gollotte et al. 1993, 1996). Although differences in gene expression among genotypes are small (except for pI 206) repetitions of this experiment gave very similar results. The P2 mutants always show consistently higher levels of defense gene expression (except for $\mathrm{CHT}$ and $\mathrm{tCAH}$ ) than wild-type plants at early stages of root interactions (6 dai) with $G$. mosseae, that is, in the period crucial for developing resistance. The same can be said for early interactions ( 1 to 3 dai) with $R$. leguminosarum (except for CHT). Temporal differences in activities of defense genes have been distinguished in resistant and susceptible plant-pathogen interactions (Daniels et al. 1987; Chiang and Hadwiger 1990; Bell et al. 1986), and it has been postulated that resistance response products have to accumulate above a critical threshold value for resistance to occur (Hadwiger and Culley 1993). Consequently, resistance to mycorrhizal fungi and Rhizobium spp. in the $\mathrm{Myc}^{-1} \mathrm{Nod}^{-}$pea mutants may be mediated by defense gene expression but at a lower level than in plant-pathogen interactions, as suggested also from PAL expression analysis in an $\mathrm{Myc}^{-1}$ alfalfa genotype inoculated with G. versiforme (Karsten) Berch (Harrison and Dixon 1993). This may be related to a lower aggressiveness of mutualistic, compared with pathogenic, microorganisms, which also leads to a lower elicitation of plant defense reactions.

The present observations reinforce the hypothesis that some common plant responses are associated with host-microbe interactions in mycorrhiza and nodulation symbioses (Gianinazzi-Pearson and Dénarié 1997). Further research is necessary to understand the extent to which plant genes are commonly modulated in symbiotic bacterial and fungal interactions with roots, and to distinguish those that are specific to symbiosis.

\section{MATERIALS AND METHODS}

\section{Plant inoculation and growth conditions.}

Surface-disinfected (ethanol 95\%, 5 min) seeds of Pisum sativum L. 'Frisson' $\left(\mathrm{Myc}^{+} \mathrm{Nod}^{+}\right)$and the isogenic mycorrhizaand nodulation-resistant $\left(\mathrm{Myc}^{-1} \mathrm{Nod}^{-}\right)$mutants P2, P6, and P54 (Duc et al. 1989) were germinated 4 days in the light at $20^{\circ} \mathrm{C}$ in autoclaved vermiculite. Pea seedlings were then transplanted into $400 \mathrm{~g}$ of an autoclaved soil/calcined clay (Terragreen) mixture (1:1, vol:vol) and inoculated or not with the fungal isolate G. mosseae (BEG 12), as described previously (Dumas-Gaudot et al. 1994), or with $R$. leguminosarum bv. viciae isolate 1007 ( $0.5 \mathrm{ml}$ of liquid suspension per pot at $\left.1 \mathrm{U} \mathrm{OD}_{600}\right)$. Noninoculated plants received the same amount of autoclaved inoculum. For comparison, other plants were watered with a suspension of zoospores $\left(10^{5}\right.$ per $\left.\mathrm{ml}\right)$ of a virulent strain (SRSF502, Agriculture Canada, Ste-Foy) of $A$. euteiches Drechs., produced according to Beghdadi et al. (1992). Plants were grown under controlled conditions (20 to $24^{\circ} \mathrm{C}$ night/day, 16-h photoperiod, $320 \mu \mathrm{mol} \mathrm{s}{ }^{-1} \mathrm{~m}^{-2}, 70 \%$ relative humidity) and watered daily. Roots were harvested for mRNA analysis at 3, 6, and 15 dai with G. mosseae for cv. Frisson and P2 plants in order to cover different stages of AM development, and at an intermediary time point (9 dai) for P6 and P54 genotypes. Plants inoculated with $R$. leguminosarum were harvested at 1, 3, 6, and 15 dai, covering from early interactions between bacteria and roots up to nodule formation. Roots infected by A. euteiches were analyzed at 6 and 15 dai and symptoms visually evaluated. Parameters of mycorrhizal colonization were determined after trypan blue staining of roots (Trouvelot et al. 1986) and nodule number was estimated by direct observation with a binocular microscope, in three replicate plants for each time point. Percentages were arcsin transformed and data were subjected to analysis of variance with time point and plant genotype as factors. Differences among means were analyzed for significance by Duncan's multiple range test (Duncan 1955).

\section{RNA isolation, synthesis of first-strand cDNA, and PCR.}

Total RNA was isolated from pea roots with the Plant Total RNA Kit (Qiagen, Hilden, Germany), following the manufacturer's protocol. DNase treatment of total RNA was performed according to the manufacturer's recommendations (Promega, Madison, WI). Total RNA $(2.5 \mu \mathrm{g})$ from nonmycorrhizal cv. Frisson roots was reverse transcribed to firststrand cDNA with MMLV-RT enzyme (Promega) and oligo $(\mathrm{dT})_{15}$ primer, in a final volume of $25 \mu \mathrm{l}$ with the buffer recommended by the enzyme supplier. A $0.7-\mu$ l aliquot was used as template for PCR in a final volume of $20 \mu$ containing $100 \mu \mathrm{M}$ dNTPs, $1 \times$ PCR buffer (Gibco-BRL, Gaithersburg, MD), $2.5 \mathrm{mM} \mathrm{MgCl}_{2}, 0.25 \mathrm{U}$ of $\mathrm{Taq}$ DNA polymerase (Gibco-BRL), and $0.5 \mu \mathrm{M}$ concentrations of specific primers (Table 2) deduced from available sequences for pea defenserelated genes encoding pI 206 (M18250), pI 49 (X13383/M18305), pI 176 (M18249), PR 10 (U65419), basic A1-chitinase (CHT, X63899), transcinnamic acid 4hydroxylase (tCAH, U29243), or chalcone isomerase (CHI, U03433). PCR was performed in a PTC-100 thermocycler (MJ Research, Watertown, MA) with the following parameters: initial denaturation at $95^{\circ} \mathrm{C}$ for $4 \mathrm{~min}$, followed by 30 cycles of denaturation at $93^{\circ} \mathrm{C}$ for $45 \mathrm{~s}$, annealing at the ap- 
propriate temperature for each primer pair (Table 2) for $45 \mathrm{~s}$, elongation at $72^{\circ} \mathrm{C}$ for $45 \mathrm{~s}$, and a final elongation at $72^{\circ} \mathrm{C}$ for 5 min.

Genomic DNA (80 ng) from nonmycorrhizal pea roots and G. mosseae spores also served as templates for PCR $(20 \mu \mathrm{l}$ total volume) with $1 \mu \mathrm{M}$ concentrations of specific primer pairs for pI 206, $125 \mathrm{nM}$ concentrations of dNTPs, $0.2 \mathrm{U}$ of Taq DNA polymerase (Gibco-BRL), and the buffer supplied by the company. PCRs were done as described above and PCR products separated in a $1.4 \%$ agarose gel for visualization by ethidium bromide staining.

\section{Cloning and sequencing of cDNA fragments.}

After Geneclean (Bio101, Vista, CA) treatment, cDNA fragments were cloned into PT7 Blue plasmid (Promega) and recombinant plasmids used to transform competent Escherichia coli XL1-Blue cells. Positive clones screened by PCR (Güssov and Clackson 1989) were subcultured and plasmidic DNA isolated according to Sambrook et al. (1989). Sequencing was performed by the dideoxy-sequencing method (Sanger et al. 1977) with fluorescent dye-linked universal primers (T7 and T3) and an Applied Biosystems model 370A DNA sequencer (Genome Express Society, Grenoble, France). Sequence similarity searches were carried out in the EMBL data bank with the FASTA program from the Wisconsin Package 8 (Genetics Computer Group, Madison, WI).

\section{Northern blot analysis.}

After electrophoresis on $1.2 \%$ agarose gel containing $2.2 \mathrm{M}$ formaldehyde, total RNA $(20 \mu \mathrm{g})$ was blotted onto Hybond- $\mathrm{N}^{+}$ nylon membranes (Amersham, Little Chalfont, UK) by capillarity (Sambrook et al. 1989). Equal RNA loading and transfer were verified by methylene blue staining of nylon membranes before hybridization, according to Herrin and Schmidt (1988) and Sambrook et al. (1989). Blots were prehybridized 2 to $3 \mathrm{~h}$ at $60^{\circ} \mathrm{C}$ in $5 \times$ Denhardt's solution, $5 \times \mathrm{SSC}(1 \times \mathrm{SSC}$ is $0.15 \mathrm{M}$ $\mathrm{NaCl}$ plus $0.015 \mathrm{M}$ sodium citrate), $0.5 \%$ SDS (sodium dodecyl sulfate), and hybridized with respective probes obtained by a PCR Radioactive Labeling System of plasmid inserts (Gibco-BRL), except for the tCAH probe, which was obtained with the Prime-a-Gene Labeling System (Promega). Unincorporated ${ }^{32} \mathrm{P}$ was removed with an S-200 HR MicroSpin column (Pharmacia Biotech, Uppsala, Sweden). A total $10^{7} \mathrm{cpm}$ probe was heat denatured and used to hybridize the blots overnight at $60^{\circ} \mathrm{C}$ under standard conditions (Sambrook et al.
1989). After being washed twice for $5 \mathrm{~min}$ at room temperature in $2 \times \mathrm{SSC}$ and $0.1 \% \mathrm{SDS}$, and once for $15 \mathrm{~min}$ at $55^{\circ} \mathrm{C}$ in the same solution, membranes were exposed for $5 \mathrm{~h}$ to Kodak X-RAY-OMAT at $-70^{\circ} \mathrm{C}$. rRNA and signals on autoradiograms were analyzed with the Alcatel-TITN image analysis system (Grenoble, France) and then quantified with NIH Image software (NIH Image is available on-line from the National Institutes of Health). Transcript accumulation levels were normalized according to the amount of rRNA in the membranes. Northern blot analyses were done twice with two different sets of plants and RNA for all the plant-microbe combinations.

\section{ACKNOWLEDGMENTS}

This work was supported by an EU research training grant to J. M. R.-L. (contract no. BIO4-CT96-5037). We thank D. van Tuinen and F. Martin-Laurent for helpful discussion, and C. Schneider and A. Hartmann for assistance with image analyses.

\section{LITERATURE CITED}

Arlorio, M., Ludwig, A., Boller, T., Mischiati, P., and Bonfante, P. 1991. Effects of chitinase and $\beta$-1,3-glucanase from pea on the growth of saprophytic, pathogenic and mycorrhizal fungi. G. Bot. Ital. 125:956958.

Beghdadi, A., Richard, C., and Dostaler, D. 1992. L'Aphanomyces euteiches des luzernières de Québec: Isolement, morphologie et variabilité de la croissance et du pouvoir pathogène. Can. J. Bot. 70:19031911.

Bell, J. N., Ryder, T. B., Wingate, V. P. M., Bailey, J. A., and Lamb, C. J. 1986. Differential accumulation of plant defence gene transcripts in a compatible and incompatible plant-pathogen interaction. Mol. Cell. Biol. 6:1615-1623.

Bowles, D. J. 1990. Defence-related proteins in higher plants. Annu. Rev. Biochem. 59:873-907.

Caetano-Anollés, G., and Bauer, W. D. 1988. Feedback regulation in nodule formation in alfalfa. Planta 175:546-557.

Calvert, H. E., Pence, M. K., Pierce, M., Malik, N. S. A., and Bauer, W. D. 1984. Anatomical analysis of the development and distribution of Rhizobium infections in soybean roots. Can. J. Bot. 62:2375-2384.

Chiang, C. C., and Hadwiger, L. A. 1990. Cloning and characterization of a disease resistance response gene in pea inducible by Fusarium solani. Mol. Plant-Microbe Interact. 3:78-85.

Collinge, D. B., Gregersen, P. L., and Thordal-Christensens, H. 1994. The induction of gene expression in response to pathogenic microbes. Pages 391-413 in: Mechanisms of Plant Growth and Improved Productivity: Modern Approaches and Perspectives. A. S. Basra, ed. Marcel Dekker, New York.

Daniels, C. H., Fristensky, B., Wagoner, W., and Hadwiger, L. A. 1987. Pea genes associated with non-host disease resistance to Fusarium are

Table 2. Primers used for the reverse transcription-polymerase chain reaction assay, annealing termperature $\left({ }^{\circ} \mathrm{C}\right)$, and expected DNA fragment size

\begin{tabular}{|c|c|c|c|}
\hline Name & Sequence $5^{\prime}$ to $3^{\prime}$ & Annealing & Fragment size (bp) \\
\hline pI 206 forward & AGCCATATAAACCATGC & 58 & 478 \\
\hline pI 206 reverse & CCAACACTCAAAGAACTTG & & \\
\hline PR 10 forward & GGTGGTGCTGGAACCATC & 52 & 351 \\
\hline PR 10 reverse & AGCTTTGTCAGTCTTGAG & & \\
\hline pI 49 forward & GGCAAGCAATTTCTTAGTT & 58 & 604 \\
\hline pI 49 reverse & GCAGCCAAATTAAGCACACA & & \\
\hline pI 176 forward & TACACAACTAGGCAAGC & 54 & 705 \\
\hline pI 176 reverse & GGAGAGGTATACATGAC & & \\
\hline CHT forward & CACAAAACCGACATACTAC & 58 & 517 \\
\hline $\mathrm{CHT}$ reverse & GCAATATCCCCACGCGTATG & & \\
\hline tCAH forward & TCGCCGCCATAACCGCCATC & 60 & 1035 \\
\hline tCAH reverse & GCTTGTAGGTAAGGTAGC & & \\
\hline CHI forward & AGGAATTCCGGCAATAAG & 52 & 601 \\
\hline $\mathrm{CHI}$ reverse & TTCCAACACTGCAGACGA & & \\
\hline
\end{tabular}


also active in race-specific disease resistance to Pseudomonas. Plant Mol. Biol. 8:309-316.

Dixon, R. A. 1986. The phytoalexin response: Elicitation, signalling and the control of host gene expression. Biol. Rev. 61:239-291.

Dixon, R. A., Harrison, M. J., and Lamb, C. J. 1994. Early events in the activation of plant defence responses. Annu. Rev. Phytopathol. 32: 479-501.

Duc, G., Trouvelot, A., Gianinazzi-Pearson, V., and Gianinazzi, S. 1989. First report of non-mycorrhizal plant mutants $\left(\mathrm{myc}^{-}\right)$obtained in pea (Pisum sativum L.) and fababean (Vicia faba L.). Plant Sci. 60:215-222.

Dumas-Gaudot, E., Asselin, A., Gianinazzi-Pearson, V., Gollote, A., and Gianinazzi, S. 1994. Chitinase isoforms in roots of various pea genotypes infected with arbuscular mycorrhizal fungi. Plant Sci. 99:27-37.

Duncan, D. B. 1955. Multiple range and multiple F tests. Biometrics 11: $1-42$.

Frank, M. R., Deyneka, J. M. and Schuler, M. A. 1996. Cloning of wound-induced cytochrome P450 monooxygenases expressed in pea. Plant Physiol. 110:1033-1046.

Fristensky, B. W., Hadwiger, L. A., and Horovitz, D. 1988. CDNA sequences for pea disease resistance response genes. Plant Mol. Biol. 11:713-715.

Fristensky, B. W., Hadwiger, L. A., Riggleman, R. C., and Wagoner, W. 1985. Gene expression in susceptible and disease resistant interactions of peas induced with Fusarium solani pathogens and chitosan. Physiol. Plant Pathol. 27:15-28.

Frühling, M., Roussel, H., Gianinazzi-Pearson, V., Pühler, A., and Perlick, A. M. 1997. The Vicia faba leghemoglobin gene VfLb29 is induced in root nodules and in roots colonized by the arbuscular mycorrhizal fungus Glomus fasciculatum. Mol. Plant-Microbe Interact. 10:124-131.

Gerhold, D. L., Pettinger, A. L., and Hadwiger, L. A. 1993. Characterization of a plant-stimulated nuclease from Fusarium solani. Physiol. Mol. Plant Pathol. 43:33-46.

Gianinazzi-Pearson, V. 1996. Plant cell responses to arbuscular mycorrhizal fungi: Getting to the roots of the symbiosis. Plant Cell 8: 1871-1883.

Gianinazzi-Pearson, V., and Dénarié, J. 1997. Red carpet programmes for root endosymbioses. Trends Plant Sci. 2:371-372.

Gianinazzi-Pearson, V., Dumas-Gaudot, E., Gollotte, A., Tahiri-Alaoui, A., and Gianinazzi, S. 1996. Cellular and molecular defence-related root responses to invasion by arbuscular mycorrhizal fungi. New Phytol. 133:45-57.

Gianinazzi-Pearson, V., Gianinazzi, S., Guillemin, J. P., Trouvelot, A., and Duc, G. 1991. Genetic and cellular analysis of resistance to vesicular-arbuscular (VA) mycorrhizal fungi in pea mutants. Pages 336342 in: Advances in Molecular Genetics of Plant-Microbe Interactions. H. Hennecke and D. P. S. Verma, eds. Kluwer Academic Pub., London.

Gianinazzi-Pearson, V., Gollotte, A., Dumas-Gaudot, E., Franken, P., and Gianinazzi, S. 1994. Gene expression and molecular modifications associated with plant responses to infection by arbuscular mycorrhizal fungi. Pages 179-186 in: Advances in Molecular Genetics of Plant-Microbe Interactions 3. M. Daniels, J. A, Downie, and A. E. Osbourn, eds. Kluwer Academic Pub., Boston.

Gianinazzi-Pearson, V., Tahiri-Alaoui, A., Antoniw, J. F., Gianinazzi, S. and Dumas-Gaudot, E. 1992. Weak expression of the pathogenesis related $P R-b l$ gene and localization of related proteins during symbiotic endomycorrhizal interactions tobacco roots. Endocyt. Cell Res. 8:177-185

Gollotte, A. 1993. Etudes cellullaires et moléculaires des intéractions racine-champignon symbiotique ou non chez des pois sensibles $\left(\mathrm{myc}^{+}\right)$ou résistants $\left(\mathrm{myc}^{-}\right)$à la mycorhization. Ph.D. thesis. Burgundy University, Dijon, France.

Gollotte, A., Gianinazzi-Pearson, V., and Gianinazzi, S. 1995. Immunodetection of infection thread glycoprotein and arabinogalactan protein in wild type Pisum sativum (L.) or an isogenic mycorrhizaresistant mutant interacting with Glomus mosseae. Symbiosis 18:6985 .

Gollotte, A., Gianinazzi-Pearson, V., Giovannetti, M., Sbrana, C., Avio, L., and Gianinazzi, S. 1993. Cellular localization and cytochemical probing of resistance reactions to arbuscular mycorrhizal fungi in a "locus a" mutant of Pisum sativum L. Planta 191:112-122.

Gollotte, A., Lemoine, M. C., and Gianinazzi-Pearson, V. 1996. Morphofunctional integration and cellular compatibility between endo- mycorrhizal symbionts. Pages 91-111 in: Concepts in Mycorrhizal Research, Handbook of Vegetation Science Series. K. G. Mukerji, ed. Kluwer Academic Pub., Dordrecht, The Netherlands.

Güssov, D., and Clackson, T. 1989. Direct clone characterization from plaques and colonies by the polymerase chain reaction. Nucleic Acids Res. 17:4000.

Hadwiger, L. A., Chang, M.-M., and Parsons, M. A. 1995. Fusarium solani DNase is a signal for increasing expression of nonhost disease resistance response genes, hypersensitivity, and pisatin production. Mol. Plant-Microbe Interact. 8:871-879.

Hadwiger, L. A., Chiang, C. C., and Horovitz, D. 1992. Expression of disease resistance response genes in near-isogenic pea cultivars following challenge by Fusarium oxysporum race 1. Physiol. Mol. Plant Pathol. 40:259-270.

Hadwiger, L. A., and Culley, D. E. 1993. Non host resistance genes and race-specific resistance. Trends Microbiol. 1:136-141.

Harrison, M. J., and Dixon, R. A. 1993. Isoflavonoid accumulation and expression of defense gene transcripts during the establishment of vesicular-arbuscular mycorrhizal associations in roots of Medicago truncatula. Mol. Plant-Microbe Interact. 6:643-654.

Harrison, M. J., and Dixon, R. A. 1994. Spatial patterns of expression of flavonoid/isoflavonoid pathway genes during interactions between roots of Medicago truncatula and the mycorrhizal fungus Glomus versiforme. Plant J. 6:9-20.

Herrin, D. L., and Schmidt, G. W. 1988. Rapid, reversible staining of Northern blots prior to hybridization. Biotechniques 6:196.

Lambais, M. R., and Mehdy, M. C. 1993. Suppression of endochitinase, $\beta$-1,3-glucanase, and chalcone isomerase expression in bean vesicular-arbuscular mycorrhizal roots under different soil phosphate conditions. Mol. Plant-Microbe Interact. 6:75-83.

Mellor, R. B. 1989. Bacteroids in the Rhizobium-legume symbiosis inhabit a plant internal lytic compartment: Implications for other microbial endosymbioses. J. Exp. Bot. 40:831-839.

Mellor, R. B., and Collinge, D. B. 1995. A simple model based on known plant defence reactions is sufficient to explain most aspects of nodulation. J. Exp. Bot. 46:1-18.

Mohr, U., Lange, J., Boller, T., Wiemken, A., and Vögeli-Lange, R. 1998. Plant defence genes are induced in the pathogenic interaction between bean roots and Fusarium solani, but not in the symbiotic interaction with the arbuscular mycorrhizal fungus Glomus mosseae. New Phytol. 138:589-898.

Moieyev, G. P., Beintema, J. J., Fedoreyeva, L., and Yakovlev, G. I. 1994. High sequence similarity between a ribonuclease from ginseng calluses and fungus-elicited proteins from parsley indicates that intracellular pathogenesis-related proteins are ribonucleases. Planta 193: 470-472.

Morandi, D., Bailey, J. A., and Gianinazzi-Pearson, V. 1984. Isoflavonoid accumulation in soybean roots infected with vesiculararbuscular mycorrhizal fungi. Physiol. Plant Pathol. 24:357-364.

Morandi, D., and Le Quéré, J. L. 1991. Influence of nitrogen on accumulation of isosojagol (a newly detected coumestan in soybean) and associated isoflavonoids in roots and nodules of mycorrhizal and nonmycorrhizal soybean. New Phytol. 117:75-79.

Niehaus, K., Kapp, D., and Pühler, A. 1993. Plant defence and delayed infection of alfalfa pseudonodules induced by an exopolysaccharide (EPS I)-deficient Rhizobium meliloti mutant. Planta 190:415-425.

Parniske, M., Schmidt, P. E., Kosch, K., and Müller, P. 1994. Plant defense responses of host plants with determinate nodules induced by EPS-defective exoB mutants of Bradyrhizobium japonicum. Mol. Plant-Microbe Interact. 7:631-638.

Perotto, S., Brewin, N. J., and Bonfante, P. 1994. Colonization of pea roots by the mycorrhizal fungus Glomus versiforme and by Rhizobium bacteria: Immunological comparison using monoclonal antibodies as probes for plant cell surface components. Mol. Plant-Microbe Interact. 7:91-98.

Phillips, D. A., and Kapulnik, Y. 1995. Plant isoflavonoids, pathogens and symbionts. Trends Microbiol. 3:58-64.

Pinto, M. P., and Richard, C. P. P. 1995. Lupinus albus L. pathogenesisrelated proteins that show similarity to PR-10 proteins. Plant Physiol. 109:1345-1351.

Riggleman, R., Fristensky, B., and Hadwiger, L. A. 1985. The disease resistance response in pea is associated with increased levels of specific mRNAs. Plant Mol. Biol. 4:81-86.

Sagan, M., Morandi, D., Terenghi, E., and Duc, G. 1995. Selection of 
nodulation and mycorrhizal mutants in the model plant Medicago truncatula (Gaertn.) after $\gamma$-ray mutagenesis. Plant Sci. 111:63-71.

Sambrook, J., Fritsch, E. F., and Maniatis, T. A. 1989. Molecular Cloning: A Laboratory Manual. 2nd ed. Cold Spring Harbor Laboratory, Cold Spring Harbor, NY.

Sanger, F., Nicklen, S., and Coulsen, A. R. 1977. DNA sequencing with chain terminating inhibitors. P. Natl. Acad. Sci. USA 74:5463-5467.

Savouré, A., Sallaud, C., El-Turk, J., Zuanazzi, J., Ratet, P., Schutze, M., Kondorosi, A., Esnault, R., and Kondorosi, E. 1997. Distinct response of Medicago suspension cultures and roots to Nod factors and chitin oligomers in the elicitation of defence-related responses. Plant J. $11: 277-287$

Spanu, P., Boller, T., Ludwig, A., Wiemken, A., Faccio, A., and Bonfante-Fasolo, P. 1989. Chitinase in roots of mycorrhizal Allium porrum: Regulation and localisation. Planta 177:447-455.

Staehelin, C., Granado, J., Müller, J., Wiemken, A., Mellor, R. B., Felix, C., Regenaas, M., Broughton, W. J., and Boller, T. 1994. Perception of Rhizobium nodulation factors by tomato cells and inactivation by root chitinases. P. Natl. Acad. Sci. USA 91:2196-2200.

Staehelin, C., Müller, J., Mellor, R. B., Wiemken, A., and Boller, T. 1992. Chitinase and peroxidase in effective $\left(\mathrm{fix}^{+}\right)$and ineffective (fix ${ }^{-}$) soybean nodules. Planta 187:295-300.

Staples, R. C., and Macko, V. 1980. Formation of infection structures as a recognition response in fungi. Exp. Mycol. 4:2-16.

Stintzi, A., Heitz, T., Prasad, V., Wiedemann-Merdonoglu, S., Kauffmann, S., Geoffroy, P., Legrand, M., and Fritig, B. 1993. Plant pathogenesis-related proteins and their role in defence against pathogens. Biochimie 75:687-706.

Trouvelot, A., Kough, J. L., and Gianinazzi-Pearson, V. 1986. Mesure du taux de mycorhization VA d'un système radiculaire. Recherche de méthodes d'estimation ayant une signification fonctionnelle. Pages 217-221 in: Physiological and Genetical Aspects of Mycorrhizae. V. Gianinazzi-Pearson and S. Gianinazzi, eds. INRA, Paris.

Vad, K., Neergaard, E., Madriz-Ordeñana, K., Mikkelsen, J. D., and Collinge, D. B. 1993. Accumulation of defence-related transcripts and cloning of a chitinase mRNA from pea leaves (Pisum sativum L.) inoculated with Ascochyta pisi Lib. Plant Sci. 92:69-79.

van Rhijn, P., Fang, Y., Glili, S., Shaul, O., Atzmon, N., Wininger, S., Eshed, Y., Lum, M., Li, Y., Fujishige, N., Kapulnik, Y., and Hirsch, M. 1997. Expression of early nodulin genes in alfalfa mycorrhizae indicates that signal transduction pathways used in forming arbuscular mycorrhizae and Rhizobium-induced nodules may be conserved. Proc. Natl. Acad. Sci. USA 94:5467-5472.

Vasse, J., Billy, F., and Truchet, G. 1993. Abortion of infection during the Rhizobium meliloti-alfalfa symbiotic interactions is accompanied by a hypersensitive reaction. Plant J. 4:555-566.

Volpin, H., Elkind, Y., Okon, Y., and Kapulnik, Y. 1994. A vesicular arbuscular mycorrhizal fungus Glomus intraradix induces a defence response in alfalfa roots. Plant Physiol. 104:683-689.

Volpin, H., Phillips, D. A., Okon, Y., and Kapulnik, Y. 1995. Suppression of an isoflavonoid phytoalexin defence response in mycorrhizal alfalfa roots. Plant Physiol. 108:1449-1454.

Walter, M. H., Liu, J. W., Dünn, J., and Hess, D. 1996. Bean ribonuclese-like pathogenesis-related protein genes (YprlO) display complex patterns of developmental, dark-induced and exogenous-stimulusdependent expression. Eur. J. Biochem. 239:281-293.

Wood, A. J., and Davies, E. 1994. A cDNA encoding chalcone isomerase from aged pea epicotyls. Plant Physiol. 104:1465-1466. 